\title{
Promoting a positive work experience for South African domestic workers
}

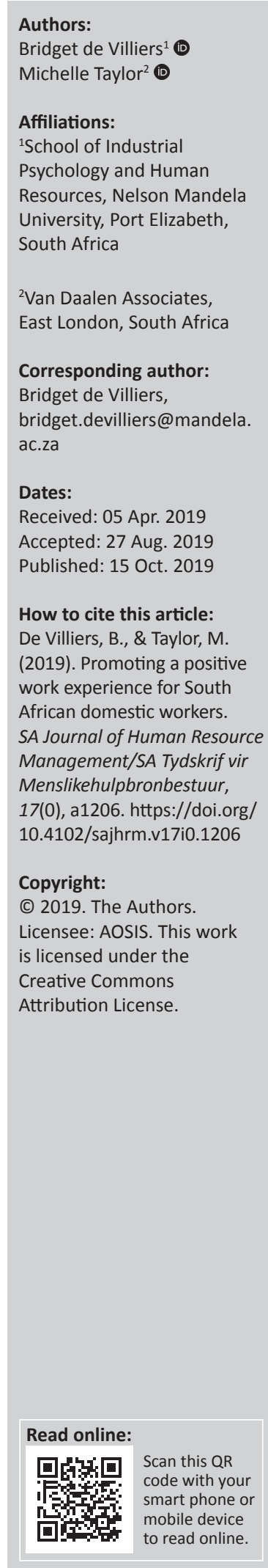

Orientation: Domestic work remains a main source of employment for many South African women. Despite legislation directed at protecting the rights of South African domestic workers, research indicates that many still experience marginalisation and a sense of powerlessness. This prompts a need to understand the factors that could enhance a positive work experience for domestic workers.

Research purpose: The purpose of this study was to explore the factors that contribute to a positive work experience for domestic workers in South Africa.

Motivation: Because of limited work opportunities and a lack of access to finance and education in South Africa, domestic work will continue to provide a source of employment in the future. It is thus important to implement strategies to enhance the positive nature of the domestic work experience.

Research approach/design and method: A qualitative design, utilising a semi-structured interview format for data collection purposes, was utilised. The sample comprised seven domestic workers and seven employers of domestic workers.

Main findings: Thematic analyses extracted job security, wages, working conditions and the relationship with employer as the most important considerations for domestic workers. Employers of domestic workers highlighted compliance with legislation, perceiving the employee as part of the family, retirement planning and respect as important factors.

Practical/managerial implications: It is proposed that employers purposefully comply with the relevant legislation to promote feelings of job security, and that domestic workers are educated in the legal requirements surrounding domestic work. Employers are further encouraged to establish open and trust-based relationships characterised by respect and consider the need for post-retirement provision. The importance of education and training in professionalising the domestic work sector is raised.

Contribution/value-add: The results of this study contribute to promoting the value and status of domestic work by providing a voice for marginalised employees and promoting a humanistic and positive work experience.

Keywords: domestic workers; humanistic management; humanising work experience; marginalised workers; positive work experience.

\section{Background to the study}

Post-apartheid South Africa is characterised by ongoing endeavours to establish equality for all citizens, including marginalised employees. Despite 25 years of democracy, South African society remains one of the world's most unequal societies (Meiring, Kannemeyer, \& Potgieter, 2018). This inequality is partly evidenced in the ongoing over-representation of women, particularly black women, in low level and unskilled occupations, including that of domestic work. According to the International Labour Organisation (ILO) (2010), domestic workers are employed in private households to undertake tasks such as cleaning, cooking, washing clothes and caring for children and/or the elderly. The domestic work sector has traditionally served as an important form of employment, more so in developing countries (Dinkelman \& Ranchhod, 2012). In South Africa, domestic work represents a substantial source of employment, with approximately 953000 black women currently active in this sector, representing $5.84 \%$ of the total South African labour force (Stats South Africa, 2019).

The South African workforce is characterised by both formal and informal employment. Formal employment provides stable and productive work with adequate earnings, whereas informal 
employment, which includes domestic work, is characterised by wages that are low in relation to the cost of living, exposure to challenging working conditions and a lack of job security (Mabilo, 2018). The informal nature of domestic work contributes to the precarious nature thereof. Precarious employment is characterised by low levels of regulatory protection, low wages, high unemployment insecurity and little employee control over wages, and working hours and conditions (Campbell \& Price, 2016). Globally, domestic workers are recognised as a marginalised group of workers who are denied access to decent work. The ILO defines decent work as productive work undertaken in conditions of freedom, equity, security and human dignity (Galvaan et al., 2015).

Progressive legislative reforms in South Africa in recent years have provided domestic workers and other lower income employees with protection within their employment contexts (Marais \& Van Wyk, 2015). Promulgated legislation includes the Basic Conditions of Employment Act, No. 75 of 1997 (BCEA), which regulates the right to decent work and fair labour practices (Finnemore \& Koekemoer, 2018), and Sectoral Determination 7: Domestic Work Sector, which regulates minimum wages and working hours amongst others (Blaauw \& Bothma, 2010). In addition, in 2013, South Africa became a signatory to the Domestic Workers Convention 2011 (No. 189) (ILO, 2010), thus indicating a commitment to achieve decent work for all. This is of significance understanding that domestic workers constitute approximately $8 \%$ of the informal employment sector, and that in South Africa the informal economy is one of the few areas of employment growth, with an increase of 220000 jobs from 2017 to 2018 (Stats SA, 2018). An ILO law and practice report in 2010 found domestic work across the world to be undervalued, underpaid, unprotected and poorly regulated - this despite the contributions of domestic workers to the care and welfare of their employers' households (Budlender, 2010).

Domestic work differs vastly from other traditionally paid work, particularly that undertaken in the formal sector. In the domestic work sector, the boundaries between employer and employee are not as well defined as those in a more typical workplace, such as an office or factory setting. Furthermore, domestic workers may experience a sense of marginalisation and powerlessness because of the largely invisible nature of their work that takes place behind the walls of private homes (Kwele, Nimako, Zwane, \& Chrysler-Fox, 2015). In addition, domestic work is not always regarded as 'actual work'. This is because of the similarity between the paid tasks of domestic workers and the unpaid tasks performed by women in their own homes (Du Preez, Beswick, Whittaker, \& Dickinson, 2010). Furthermore, Dinkelman and Ranchhod (2012) contend that legislative protection is difficult to monitor and enforce in private households because of the limited availability of resources to do so.

The completion of domestic tasks requires the presence of the worker in the home. Technological advances in household appliances have created an expectation of the elimination of human assistance in households, but this has been countered by the increasing needs of professional working people for assistance in coping with the double burden of family and career (Lutz, 2002). Although advances in technology may ultimately replace the human element for certain domestic chores such as cleaning, cooking, planning children's activities and reminding the elderly to take their medication, other activities such as soothing a baby and encouraging an old person to make the effort to stand up may not be so easily achieved (Brizi \& Bertolaso, 2017). The authors contend that domestic workers will remain pivotal to the smooth running of many households worldwide. They further assert that the value of domestic work lies in the enabling, empowering and emancipating impact that it contributes to the flourishing of society. Marais and Van Wyk (2015) add to this in stating that domestic workers deserve recognition as significant contributors to, and enablers within, the world economy.

Pre-democracy research on the domestic work sector in South Africa has highlighted the factors that contributed towards feelings of oppression experienced and related to long hours worked, low wages and racial inequality (Cock, 1980; Gaitskell et al., 1984). More recent studies have explored the impact of minimum wage legislation in the domestic work sector (Blaauw \& Bothma, 2010; Dinkelman \& Ranchhod, 2012), experiences within the domestic employment relationship (Bosch \& McLeod, 2015; Galvaan et al., 2015) and factors influencing the choice for continued employment in the domestic work sector (Marais \& Van Wyk, 2015). These later studies contributed to an in-depth understanding of the domestic work experience, and the factors that determine the nature of this experience.

The aim of this study was to identify the factors in the context of South African domestic work that promote a positive work experience by reflecting on the experiences of domestic workers and employers of domestic workers. Within the context of this study, a positive work experience is one that is characterised by elements that promote a humanising work environment (Ryan, 2016). A humanising work environment acknowledges that the human element is the most important in any employment relationship. This is achieved through the practice of humanistic management. Humanistic management is described as one that emphasises the human condition and focuses on the development of human virtue by considering the situational and personal circumstances of the employee (Melé, 2013).

\section{Research purpose and objectives}

Understanding the ongoing importance of domestic work as a form of employment in South Africa, the purpose of this study was to identify the factors in the context of South African domestic work that promote a positive work experience. This knowledge is valuable in determining strategies to enhance the positive nature of this experience. Specific research objectives included the following:

- to explore the work experiences of domestic workers in a South African context 
- to explore the theory on humanistic management in promoting a positive work experience

- to identify specific factors that contribute towards a positive work experience for domestic workers in South Africa.

\section{Literature review \\ The nature of domestic work}

Domestic workers are entrusted with caring for the family's most valued assets, including children, the elderly and the home. Meyiwa (2012) highlights an unwillingness to acknowledge the contribution of these women, who are depended on to run the household smoothly and who perform duties that would otherwise be incumbent on the employer. Through this contribution, domestic workers enable their employers and other family members to work apart from the home or pursue other interests. In this way, they actively contribute to the prosperity of the societies in which they work through fostering human development, productivity and economic growth (Brizi \& Bertolaso, 2017). In many instances, domestic workers trade a working opportunity for a significant loss in time spent with their own families and involvement in their own communities (Mangqalaza, 2012).

The practice of employing domestic workers in private homes is a long-standing global phenomenon. Factors such as the ageing of the world population, the insufficiency of state care provision for children, the elderly and the infirm, as well as the increased participation of women in the workplace have amplified the demand for domestic workers, particularly in relation to care services (Brizi \& Bertolaso, 2017; Lutz, 2002). In a study conducted by Blaauw and Bothma (2010), it was found that the percentage of domestic workers performing childcare duties in South Africa almost doubled in the period $2001(8 \%)$ to $2006(14 \%)$, which suggests an increased number of mothers entering employment over that period.

The domestic labour force is viewed as precarious and particularly vulnerable to discrimination with respect to conditions of employment (Budlender, 2010), despite the validation of various acts to formalise and more closely regulate domestic work (Dilata, 2008). While the minimum wages stipulated in Sectoral Determination 7 have increased over time, high levels of unemployment in South Africa lead to situations where workers are prepared to accept below minimum wages offered to them by employers, despite this being an infringement of law (Du Toit, 2010). Surveys conducted in South Africa revealed that one out of five participants admitted to paying their domestic workers less than the minimum wage (Businesstech, 2018).

For better understanding the domestic work experience, it is important to reflect on the atypical nature of the domestic employment relationship. Qayum and Ray (2003) contend that the conceptual divide that would normally prevail in a more traditional employer-employee relationship is blurred in the employer-domestic worker relationship. Hansen
(1989) alluded to the 'peculiar personalness' of the domestic employment relationship, which takes place with in an intimate space. This 'confuses and complicates the divide between family and work, custom and contract, affection and duty, the home and the world' (Qayum \& Ray, 2003, p. 521). Hua and Ray (2010) echo this sentiment.

The nature of domestic work is such that household members play a key role in determining the day-to-day working conditions of these workers (Brizi \& Bertolaso, 2017). In addition,, the tendency of some employers to make use of the family metaphor to depict the employment relationship masks the reality of an unequal power relationship. This metaphor allows the employer to shift between a contractual or familial approach to the relationship, based on what suits the employer at a specific point in time (Du Preez et al., 2010). Furthermore, employers of domestic workers are not a homogeneous group, which leads to differing expectations regarding the skills required from domestic workers (Brizi \& Bertolaso, 2017). This individualised employment relationship (Marais \& Van Wyk, 2015) largely excludes domestic workers from decision-making processes, and they consequently have little or no bargaining power concerning the determination of working conditions.

\section{The South African domestic work experience}

Africa follows Asia (1) and Latin America and Caribbean (2) as the third largest employer of domestic workers globally, and the majority are employed in South Africa (Marais \& Van Wyk, 2015). Research undertaken by Stats SA indicated that for the first quarter of 2019, domestic work accounted for $6.22 \%$ of the total workforce, of which $96 \%$ were women (Stats SA, 2019). The domestic work sector in South Africa is largely composed of poorly educated black and mixed race women (Dinkelman \& Ranchhod, 2012). In South Africa, the apartheid regime was responsible for enacting legislation that limited educational and work opportunities for people based on race. Black women were prohibited from most forms of work. This, coupled with the poor Bantu education system, led to high levels of illiteracy and limited skills acquisition (Du Preez et al., 2010). Black women consequently comprise most of the current South African domestic labour force. Marais and Van Wyk (2015) believe that poverty is a primary reason that still drives young girls to enter the domestic work sector. Household poverty is cited as one of the main reasons why South African learners leave school (Weybright, Caldwell, Xie, Wegner, \& Smith, 2017) and enter the informal work sector, including that of domestic work. Marais and Van Wyk (2015) contend that although low levels of formal education may have historically limited career options for black women, the high level of unemployment in South Africa has led to a situation where educated women, regardless of race, would be prepared to consider domestic work as a source of employment.

Despite the enactment of labour legislation to eliminate unfair labour practices, challenges are experienced. A study conducted by the South African Labour and Development 
Research Unit in 2010 revealed that domestic worker wages increased by about $20 \%$ in the 16 -month period following the implementation of minimum wage legislation and the probability of an employee having a formal contract doubled. However, this was not accompanied by a significant reduction in hours of work (Dinkelman \& Ranchhod, 2012). At the same time, Du Preez et al. (2010) found that a large percentage of employers were paying below the set minimum wage, did not pay unemployment insurance and did not have a formal written contract of employment in place. A lack of adherence to the relevant labour legislative provisions is seen to exacerbate the power disparity within the employment relationship (Marais, 2014).

In South Africa, the analogy of being part of the family is sometimes used to describe the relationship between domestic workers and their employers, more particularly in the case of live-in domestic workers (Tolla, 2013). In this relationship, a female employer typically takes on a maternal role, in which she leads, disciplines, is concerned for and assists her employee in the same way that she would do her own children (Du Toit, 2010). Maternalism may have been seen as a one-way relationship where the actions of the employer, such as giving gifts and financial support, could be a way to elicit loyalty from the employee. King (2007) cited in Bosch and McLeod (2015) referred to this arrangement as pseudo-maternalism, in the sense that the apparent caring, nurturing and empathy may mask a curtailing of the rights of adult employees. Parrenas (2001) disputes the maternal nature of the domestic employment relationship, stating that it is mutually beneficial. The author states that employers can use the notion of being part of the family to elicit behaviour over and above that of the employee's duties, such as housesitting when the employer is away, and the domestic worker can use this to her advantage through, for example, receiving gifts and money. Khunou (2018) challenges this view stating that practices such as passing on old clothes and giving gifts could lead to exploitation should domestic workers feel obliged to accept this in return for working longer hours or reduced wages. In her study exploring caring and connectedness in the context of domestic work, Marais (2016) found that these actions were not seen to be one-sided; instead, there was a perception of a give and take, and hence an attitude of mutual caring and commitment. This was seen as demonstrating reciprocal support within the employeremployee relationship. Galvaan et al. (2015) describe the difficulties experienced by employers in navigating the domestic employment relationship in the sense of the employer fulfilling a mothering role while continuing to maintain a professional working relationship with her employee, particularly so when the domestic worker is responsible for looking after the employer's child(ren).

Donald and Mahlatji (2006) highlight that domestic workers in South Africa may experience a sense of disempowerment in the workplace because of the actions of employers. These include the demonstration of a lack of trust regarding household items, differential treatment in the provision of food and utensils, locking valuables away and implementing wage deductions for household items broken. Galvaan et al. (2015) highlight practices such as the rationing of food and handing over leftovers to domestic workers, directing meal times and determining where and with whom the domestic worker should eat as reinforcing a social divide. In contrast, participants in Marais's (2016) study reported on the importance of open communication, and spoke about conversations surrounding employment conditions, the resolution of disputes and the sharing of personal joys and hardships.

\section{Humanistic management and a positive work experience}

Dierksmeier (2016) contends that multiple crises faced in the 21st century largely share a common denominator, that is, an economic system that holds little regard for human values and virtues. A disregard for moral norms is seen to contribute to many of the social and ecological problems experienced in the world today. As a result, many businesses are contemplating their role in broader society. This is reflected in a growing interest in business theory and management practices that focus on shifting from capitalistic to humanistic business practices (Dierksmeier, 2016). This shift includes a focus on humanistic management, which, in its broadest sense, entails a concern for people and human aspects in managing organisations. A humanistic management approach is oriented not only to obtaining results through people, but also towards showing care for the flourishing and well-being of people (Melé, 2016).

Humanistic management upholds the unconditional human dignity of all people within an economic context (Spitzeck, 2011). Melé (2013) defines humanistic management as emphasising the human condition, oriented towards the development of human virtue, and viewing employees as contributing freely and with a sense of responsibility and awareness to organisational objectives. According to this approach, employees are regarded as both rational and emotional, and as possessing talent and creativity. In addition, employees can be motivated to cooperate, can work with high or low morale and can develop feelings of either pride or resentment towards the organisation (Melé, 2016). The author thus asserts that from a management perspective, it is important to promote self-determination at work. This requires treating employees with respect and focussing on their well-being, satisfaction and self-actualisation. Acevedo (2012) describes humanistic management as affirming human beings as human persons.

Dierksmeier (2016) argues that affirming the unconditional dignity of human life requires consideration of the conditions under which dignity can flourish. A humanistic focus on dignity thus goes hand in hand with the fostering of humane life conditions, which, in turn, demands promoting the capabilities of people so that all can freely achieve a life they have reason to value. The author contends that humanistic management entails an unconditional commitment to a business orientation that is of service to human dignity and that promotes the flourishing of human life. Flourishing 
requires a reciprocity in work relationships, which, in turn, necessitates active and meaningful engagement between an employer and an employee, leading to an overall sense of well-being. This can lead to a caring connectedness forming between the employer and employee based on mutual respect and trust (Marais, 2016).

Spitzeck (2011) developed an integrative model of humanistic management that considers the duality of morality and profitability faced by organisational leaders, as depicted in Table 1.

Table 1 maps the dimensions of profitability and morality on a $2 \times 2$ matrix with four resulting quadrants. Quadrant I is described as profitable and evil, and as depicting an organisation that engages in business activities to the detriments of human dignity, such as the Mafia, who engage in extremely profitable drug and weapon trading. Quadrant IV is described as responsible, but unprofitable, and would more typically characterise a non-governmental organisation that fails to consider economic viability. An organisation situated in Quadrant III would not possess the moral or financial resources to exist and is thus considered irrelevant in a business context. Quadrant II combines the two dimensions in a virtuous manner and describes organisations that have developed financially attractive business models and practices that respect human dignity and offer products and services that address genuine human needs in a way that respects the concerns of all stakeholders (Spitzeck, 2011).

Carr, Parker, Arrowsmith, Haar and Jones (2017) describe a humanistic workplace as one that provides employees with opportunities to experience a sense of contribution and achievement. Characteristics of a humanistic workplace include empowerment, reward and recognition, good working conditions, job security, challenging work and growth opportunities. Experiences with these elements lead to higher levels of job satisfaction and improved work performance To achieve this, Acevedo (2012) highlights the

TABLE 1: Integrative model of humanistic management.

\begin{tabular}{lll}
\hline Dimension & Non-humanistic & Humanistic \\
\hline Profitable & I & II \\
& Challenge for society & Humanistic management \\
Not profitable & III & IV \\
& Irrelevant & Challenge for the organisation \\
\hline
\end{tabular}

Source: Adapted from Spitzeck, H. (2011). An integrated model of humanistic management. Journal of Business Ethics, 99(1), 51-62. https://doi.org/10.1007/s10551-011-0748-6 importance of ensuring that the way in which organisational activities are led and the manner in which technological, informational, material and financial resources, including profits, are administered must affirm human dignity.

Several developments have taken place over time, which have influenced the field of humanistic management. Melé (2013) highlights some of these developments as indicated in Table 2.

The most current contributions pertaining to positive organisational scholarship focus on positive processes, value transparency and extending the range of what constitutes a positive organisational outcome. Positive organisational scholarship specifically highlights the role of organisations in fostering excellence, and a sense of thriving, flourishing, abundance and resilience amongst employees. As noted by Melé (2013), positive organisational scholarship is not only a theory but also an umbrella covering different approaches focusing on positive phenomena in the workplace that bring about what is considered positive or desirable. The household in which the domestic worker is employed is a workplace. Domestic workers, as with any other employees, are not economic assets and valued only for their productivity, but individuals have complex needs and a desire for meaningful work and a positive work experience (Thompson, n.d.). Through understanding the experiences of domestic workers, this study aimed to identify the factors that contribute towards a positive work experience.

\section{Research design and methodology}

This exploratory study, which was qualitative in nature, used a phenomenological research design. From this perspective, behaviour is seen as a product of how the individual interprets the world (Bryman \& Bell, 2011), and the research design used to understand the everyday lived realities as voiced by participants. In this study, the perceptions of domestic workers, working in private households, with different sets of circumstances, different tasks, different work methods, different relationships and varying benefits were sought. In addition, the perceptions of employers of domestic workers were also sought. These employers were not the employers of the participating domestic workers.

\section{Population, sampling technique and sample}

The target population of this study comprised domestic workers located in the Eastern Cape province of

TABLE 2: Developments contributing to humanistic management.

Development
The importance of person-organisation fit
The increased importance of people's involvement in organisations
The consideration of business as a community of persons
Adopting a comprehensive approach to decision-making
Managing and integrating the relationships and interests of all organisational
stakeholders
The introduction of value-based management, business ethics and corporate
social responsibility
The increasing importance of personal competences, including moral character
The contribution made by positive organisational scholarship

Contributor(s)

Taylorism; Fordism; Kristof (1996); Cable and Judge (1994); Chatman (1989); Judge and Bretz (1992) Follett (1940); Pfeffer and Veiga (1999)

Handy (1999); Solomon (1992; 1994); Hansen (1999); Uzzi (1996); Kogut and Zander (1995); Nahapiet and Ghoshal (1998); Cohen and Prusak (2001); Moran (2005); Mele (2012) Perez-Lopez (1991; 1993)

Freeman (2004); Argandona (1998; 2011)

Barnard (1968); Anderson (1997); Blanchard and O'Conner (1996); McCoy (1985); Burns (1978); Greenleaf (1997); Ciulla (2004); Sison (2003)

Mele (2012); Collin (2001)

Cameron, Dutton and Quinn (2003); Cameron and Spreitzer (2011)

Source: Melé, D. (2013). Antecedents and current situation of humanistic management. African Journal of Business Ethics, 7(2), 52-61. https://doi.org/10.4103/1817-7417.123079 
South Africa. Because of the primary researcher being based in East London, situated in the Eastern Cape province, the study was conducted in that area. Two groups participated in the study, namely, seven domestic workers employed in and seven employers of domestic workers based in the metropolitan area of East London. The participation of the domestic workers was obtained through convenience sampling. This was achieved by approaching the coordinator of an outreach initiative that offered basic computer training to domestic workers at a local church. The coordinator was contacted, the researcher explained the purpose of the study and permission was requested and granted to inform domestic workers attending the training about the study. On an evening when the training was taking place, the researcher read a prepared brief that explained the purpose of the study and asked whether any of the domestic workers would be willing to participate. The group was further informed that participation was voluntary, that participants had the option to opt out at any stage of the process, that their participation would be anonymous and that information disclosed would remain confidential. Following this information sharing, participants were included in the study based on their willingness to participate.

Inclusion criteria set by the researcher included that the participants must be employed to perform household chores within a private household and worked for a minimum of 6 $\mathrm{h}$ per day, for 3 days per week, for a single employer. These inclusion criteria were set to ensure some form of homogeneity amongst the respondent group, understanding that the experiences of part-time employment may differ from that of live-in employment. There is an increasing trend to employ domestic workers on a part-time basis. Bosch and McLeod (2015) highlighted a decrease in live-in in favour of live-out and char work since the dawn of democracy in South Africa. A study conducted by Marais (2016) revealed a live-in employment status of only $25 \%$ in South Africa

To access the employers of domestic workers, a request was made on a local social media group for interested parties to contact the researcher. The employers selected were not those of the participating domestic workers to avail any concerns regarding confidentiality because of the potentially sensitive nature of information disclosed.

The seven domestic workers who participated in the survey were all black women, with an average age of 43 years. None of these women were married, with one indicating that she was in a relationship, two suggested that they were single and four mentioned that they were divorced. One of the women indicated that she had no children, one had six children and the others had one child each. In terms of education, two participants stated that they had completed grade 12, one had grade 8 and one possessed no formal education. In establishing a climate of trust and rapport with the participants, the researcher felt that for three of the participants, it was respectful not to enquire about their education. The seven employers of domestic workers were all white women, with an average age of 47 years. All but one indicated that they were married, and most had between one and three children, with one indicating that she had no children. One participant stated that she held a matriculation qualification, and the others all possessed tertiary qualifications, ranging from a diploma to a master's degree.

\section{Data collection, processing and analysis}

As a phenomenological study, semi-structured interviews were deemed an appropriate method for data collection, as they allowed the researcher to create a relationship of trust through good rapport and empathetic listening (Marais, 2014). Data were collected through holding individualised semi-structured interviews, which may be described as a conversation with a purpose (Wilson \& McLean, 2011). Non-maleficence was ensured through the researcher clearly communicating the purpose of the study to the participants, and through negotiating the best location for the holding of the interviews. These interviews were held in a relaxed public setting to allow participants to feel at ease (Marais, 2014), were audio-recorded and later transcribed for further analysis. The researcher requested permission to make notes, which were used to supplement the audio recordings. All participants were reminded that they had a choice to participate in as well as withdraw from the interview process.

Data were gathered from the domestic workers and employers of domestic workers by asking the questions listed in Table 3, which were followed by further questions to gain clarity where necessary.

The questions listed in Table 3 formed the basis of the interview schedule. In choosing these questions, the researcher consulted with the questions posed in a study conducted by Tolla (2013), in which the experiences of domestic workers were explored. For the current study, questions were posed in a manner aimed at eliciting positive and negative work experiences. The opening question aimed

TABLE 3: Interview questions for domestic workers and employers.

\begin{tabular}{|c|c|}
\hline Domestic workers & Employers of domestic workers \\
\hline $\begin{array}{l}\text { 1. Tell me a little about yourself and your life (e.g. marital status, children, where your } \\
\text { home is, level of education). }\end{array}$ & $\begin{array}{l}\text { 1. Tell me a little about yourself and your life (e.g. marital status, children, where your } \\
\text { home is, level of education). }\end{array}$ \\
\hline 2. What are the aspects of your work that you enjoy? & 2. What aspects of domestic work do you think domestic workers find more enjoyable? \\
\hline 4. What could be performed to make your work experience more enjoyable? & $\begin{array}{l}\text { 4. What could be performed to make the domestic workers' work experience more } \\
\text { enjoyable? }\end{array}$ \\
\hline $\begin{array}{l}\text { 5. Is there anything else that you would like to add about your life as a domestic } \\
\text { worker? }\end{array}$ & $\begin{array}{l}\text { 5. Is there anything else that you would like to add about your perceptions of life as } \\
\text { experienced by a domestic worker? }\end{array}$ \\
\hline
\end{tabular}


at gaining demographic and other information, and questions posed thus moved from gathering general to specific information (Tolla, 2013).

Thematic analysis was used to analyse the data collected in this study. Wilson and MacLean (2011) state that thematic analysis allows for the identification of common themes within a complete data set. It entails identifying, analysing and reporting on themes identified within data, and minimally organises and describes a data set in rich detail. The researcher followed the six-phased approach proposed by Braun and Clarke (2006) in identifying themes. This entailed data familiarisation, generation of initial codes, searching for themes, reviewing themes, defining and naming themes and creating a final report. Thematic analysis is considered a flexible technique because it is not necessarily linked to a particular theoretical framework (Wilson \& MacLean, 2011). It was deemed an appropriate analysis technique for an exploratory study aimed at revealing areas for relevant future research.

\section{Ethical considerations}

Permission to conduct the study was obtained from the Nelson Mandela University Research Ethics Committee (H18-BES-HRM-004)

\section{Results and discussion of main findings}

A discussion of the results provides an analysis of the various dominant themes that emerged during the semi-structured interviews held with domestic workers and employers of domestic workers.

\section{Themes emerging for domestic workers}

Themes emerging from domestic workers' responses centred on job security, wages, working conditions and the relationship with the employer.

\section{Job security}

Job security emerged as a dominant theme. Because of the largely 'invisible' nature of domestic work (Dilata, 2008), employers do not always abide by the relevant labour legislation, including the provisions of the Unemployment Insurance Act, No. 63 of 2001. This act requires that an employee who works for more than $24 \mathrm{~h}$ a month should be registered with the Unemployment Insurance Fund (UIF) and the onus is on the employer to do so (South African Revenue Services, 2017). However, most of the domestic workers interviewed in this study were not registered and stated that this made them feel as if they were not permanently employed. One domestic worker was of the impression that the paying of UIF constituted permanent employment, and another was not sure if she was registered. A further respondent mentioned working for two employers, neither of whom had registered her. All of the participants were aware of the UIF regulation but did not exercise their rights in this regard, preferring to remain silent. Marais and Van Wyk (2015) contend that domestic workers confronted by less than favourable employment conditions remain silent because it is the only option that they have if they want to remain employed. Employees who were registered felt less vulnerable, citing unemployment and maternity benefits afforded as the reason for this.

\section{Wages}

The domestic workers interviewed confirmed the global phenomenon of poor wages and long working hours (ILO, 2010), stating that their wages were insufficient to live on, particularly because of the need to support an extended family. Magwaza states that many domestic workers support a number of dependents with their single salaries. The domestic worker is often the head of the household, and the sole family breadwinner. While this might hold absolute poverty at bay, it remains a challenge in terms of the longterm sustainability and upliftment of these families (Magwaza, 2008).

Many respondents also spoke about extremely long hours of work and unpaid overtime. One respondent, who worked for two different employers, reported a largely positive work experience in stating that 'I am happy with everything ... except money'. Another stated that she had received only R140 per day since 2016, and a further one stated that she worked 6 days a week, from half past five in the morning until five in the afternoon, with a monthly pay of R2500. Although the latter amount is marginally below the minimum wage stipulation of R2545 per month for workers in metropolitan who work for $27 \mathrm{~h}$ a week or more (Department of Labour, 2018), it seems apparent that employers may not be adhering to the minimum conditions of employment pertaining to hours of work and overtime pay as stipulated by the BCEA.

The notion of unequal power balance alluded to earlier in this article influences the ability of domestic workers to negotiate in relations to their wages. Responses in relation to income included phrases such as 'I don't complain', 'I'm not complaining ... there is nothing much to do here' and 'it's not legal ... but I am keeping quiet because I need the job ... if I complain, after that he can say ok you can go'. The unwillingness to be seen as complaining is regarded as further evidence that domestic workers lack voice and power in the employment relationship. It is important to note that most of the participants in this study revealed that they were aware of their rights concerning minimum wages. This was expressed through statements such as 'listening to the radio about domestic workers and about the money' and 'they (employers) must sit down with me and say that they have heard about the radio or TV or newspaper that they know about the law about domestic workers'. This finding is in contrast to the findings of Du Preez et al. (2010), who reported that worldwide studies indicate that very few employers or employees are aware of legislation governing domestic work and changes to this legislation. 
A couple of the participants expressed uncertainty as to whether they would receive an increase, and, if so, what the increase would be. While the women in this study felt exploited in this regard, they highlighted the high unemployment rate in South Africa and indicated that a small salary is better than no salary at all. Following the introduction of minimum wage legislation in South Africa, employers had three options: pay the minimum wage, discharge their workers or reduce the working hours through making use of part-time work. This has led to an increase in the number of domestic workers working for more than one employer, as increasing numbers of employers choose to employ domestic workers on a part-time basis (Blaauw \& Bothma, 2010). This finding provides support for the concern that domestic workers have regarding job loss or reduced hours should they raise their voices.

\section{Working conditions}

In general, the participants in this study expressed satisfaction with their hours and conditions of work, which is seen to indicate a positive work experience, with the exception of two participants who felt that they worked for more hours. One of them spoke about working 7 days a week, with excessive unpaid overtime. This respondent stated that:

'[I have ] no time to stay with my family ... If I am not working on the weekend I would be happy ... I would be happy if I could start working at $07 \mathrm{~h} 00$ or $07 \mathrm{~h} 30$, and then finish at $17 \mathrm{~h} 00 . '$

This employee was required to start working at 05:30 and her family lived in the Transkei, located in the rural Eastern Cape - a considerable distance from her place of employment. Another woman started working at 05:30 had to work 6 days a week and relied on her mother in the Transkei to look after her children. The difficulty that domestic workers experience in getting time off from work remains an issue of concern (Cock, 1980; Dilata, 2008) - this despite the BCEA provisions regarding overtime pay and working hours per week (Department of Labour, 2001). One respondent noted that she was not required to work on public holidays, which reduced her income. Employers may engage in this practice to avoid the overtime rate as stipulated by the BCEA.

The participants also expressed difficulties regarding annual leave, with a respondent stating that she had 'no holidays, and no off' during the 3 years that she had been employed by her current employer, with the exception of 2 weeks during Christmas. Long working hours and little leave result in domestic workers (mothers) being isolated from their families (Tolla, 2013), and experiencing what Henderson and Anetos (2018) refer to as both an economic and social deficit. Lutz (2002) highlighted the plight of the many women who are not allowed, or able, to have their children with them, and have to leave them with a paid substitute mother or relative.

It is noted that none of the participants in this study spoke about negative or unpleasant physical conditions related to their work experience. This is in contrast to the findings of
Hua and Ray (2010) who reported about the potential dangers associated with paid domestic work, including exposure to hazardous and toxic chemicals, chronic pain and injury, exposure to humiliating and increasingly sophisticated technologies of surveillance, undernourishment and sleep deprivation, and isolation and loneliness.

\section{Relationship with employer}

In relation to this theme, all of the participants reported a positive working relationship with their employers and said that they felt free to discuss work-related problems in an open and honest manner. However, some of the comments made in this regard were noted. One respondent reported, 'if they don't like things, they talk to me and they don't shout at

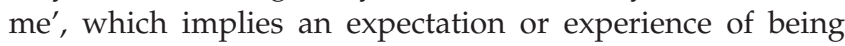
shouted at in past employment situations. Another respondent reported that she found it difficult to talk about issues that did not relate directly to her work. A further respondent mentioned that the situation determined whether she felt comfortable to talk to her employer or not:

'For instance, when the margarine is finished, I'm not feeling free ... I feel that it is her duty to check if I have margarine ... but for instance, see if there is no dishwashing soap, I feel free.'

A respondent highlighted that her employer regarded it as acceptable if she did not complete certain tasks, as her main responsibility was to care for the employer's 2-year-old daughter. Another respondent mentioned feeling comfortable because her employer was fluent in isiXhosa, which highlights the need to consider the role of spoken language in the employment relationship. The emotional and relational complexity of the domestic employment relationship in some ways overrides the role played by an employment contract and fair legislation in guaranteeing the rights of these workers. The human factor is a key element in the way this relationship unfolds within private households (Brizi \& Bertolaso, 2017).

It is critical to bear in mind that, while sacrificing time away from their own families and households, domestic workers are tending to the personal comfort and convenience of the employer's family. As such, they are enabling members of the household to work elsewhere (Brizi \& Bertolaso, 2017). The authors assert that the domestic worker plays a crucial role as an enabler for members of the household by relieving them of household tasks and taking up the role of guardian of the home. Marais and Van Wyk (2015) highlight the significant contribution made to the global economy through the enablement provided by domestic workers. This enabling influence must be acknowledged and elevated from the shadows of what is largely an invisible and underestimated job (Brizi \& Bertolaso, 2017). The authors highlight the responsibility of restoring human dignity to the domestic worker both through a protective legal framework and by acknowledging the inherent value of their empowering presence.

\section{Themes emerging for employers of domestic workers}

Themes emerging from employers of domestic workers centred on compliance with legislation, perceiving the 
employee as part of the family, retirement planning and respect.

\section{Compliance with legislation}

The domestic workers interviewed expressed not being registered for UIF as a great concern as it created a sense of employment insecurity. Literature reviewed suggests that employers tend not to register employees for UIF, as there is little to no threat of policing by authorities (Fish, 2006; Tolla, 2013). However, in this study, it was found that the majority of the employers had registered their employees, with only one acknowledging that registration 'is something that I need to do'.

\section{Part of the family}

The notion of the domestic worker being regarded as part of the family emerged as a theme for all of the employer participants. Domestic workers were seen to play a role in bringing up children, caring for them in the absence of their parents and being a second mom to them. One respondent highlighted an intimate and trusting relationship when she stated, 'when I was going through difficulties in my relationship, I cried on her shoulder. She supported me and was there for me when I needed her'. Another spoke about supporting her employee when the employee's brother was sick at home, at the time of his passing and with financial assistance for his funeral. Employers spoke about having their employees' best interests at heart, through assisting with transporting goods to their homes, taking ill employees for appropriate medical attention, providing loans when needed, providing comfortable clothing and taking an interest in their families. These findings suggest employment relationships characterised by mutual caring, and the willingness of employers to contribute more than required by the relevant labour legislation. The principles of humanistic management emphasise unconditional human dignity and equality (Acevedo, 2012; Spitzeck, 2011). Employers have a role to play in encouraging human dignity through developing their domestic workers' self-esteem and selfefficacy (Acevedo, 2012). The role of the employer in building esteem is important, considering the isolated nature of domestic work that does not allow for the sense of belonging and inclusion usually associated with working in an office or factory setting, and which contributes to feelings of fulfilment and self-respect (Mantouvalou, 2006).

\section{Retirement planning}

A study conducted by Blaauw and Bothma (2010) revealed the average age of domestic workers to be 43.3 years, a marked increase from the average age of 39.2 years found in a study conducted in 1997. This suggests that domestic work is becoming a profession of older women, for a number of reasons, including that their dependents are required by law to attend school and that young people are overqualified for domestic work, unattractive income levels and job uncertainty. Limited alternative job opportunities also encourage incumbents to remain in domestic employment.
Because of the low minimum wages of R2545 for domestic workers ( $27 \mathrm{~h}$ or more per month) (Department of Labour, 2018), and an even lower state pension of R1780 per month (South African Government, 2019), preparing for retirement is a major challenge for domestic workers. This is further complicated by the fact that many of these women support extended families. During the interviews, employers expressed their concern in this regard. One employer reported that she had taken out both a pension and a medical aid policy for her employee, while others acknowledged that they should already have performed something in terms of retirement provision. The concern noted here is that many domestic workers remain trapped in a cycle of poverty when they stop working. Tolla (2013) found that many domestic workers felt that their employers had a responsibility for providing a pension fund, as their low wages made it difficult for them to save. Lutz (2002) highlights the fact that while creating a home for their employers, domestic workers are providing financially for their own families. As such, they are not preparing for their retirement, and many of these women thus become dependent on the income of children. Marais and Van Wyk (2015) contend that for domestic workers, retirement is fraught with problems, one of these being the hardship and poverty that they will face without any form of income. For this reason, many domestic workers resume work after retirement. In their study considering exit strategies for domestic workers, the authors found that participants accepted it as given that they would have to work until they died, with some alluding to 'double dipping' in the sense of claiming social security benefits after the age of 60 while continuing to work.

\section{Respect}

A certain degree of respect is accorded to domestic workers through the private household being recognised as a workplace through the implementation of a minimum wage (Roy, 2011). It is also implied in the notion of considering domestic workers as part of the family, but research has indicated to the contrary, as extensive literature bespeaks the exploitation of domestic workers (Ally, 2011; Byrd, 2010; Donald \& Mahlatji, 2006; Du Preez et al., 2010; Maboyana \& Sekaja, 2015; Marais, 2014).

The employer participants in this study expressed concern in this regard. One employer cited the difficulty that her domestic worker experienced in discussing issues pertaining to income, borrowing money and annual leave. This challenge highlights the importance of establishing a culture of dignity and respect, through open and trust-based communication. Two employers reiterated the importance of teaching their children to respect their domestic workers, and another mentioned that having a domestic worker should not be seen as a form of entitlement. Yenn (2014) affirms that the treatment that domestic workers receive in the workplace is a function of the values and culture of a society and taught through daily practice. If a culture of respect and dignity is practised, children in homes with domestic workers grow up learning 
valuable lessons regarding class, gender and equality, and treating others with respect (Qayum \& Ray, 2009).

\section{Implications and recommendations}

The findings of this study have important workplace implications. These implications are not only limited to the domestic workplace but also to other work environments in which workers experience a sense of marginalisation or vulnerability because of the nature of their work. A developed society is one that cares for vulnerable people and protects them from the turns and twists of fate (Brizi \& Bertalosi, 2017). Many South Africans are not able to access meaningful work because of a lack of education, finances and other resources. Employers and managers can assist in enhancing a positive work experience for these employees through implementing the strategies suggested in these implications.

\section{Compliance with legislation}

Based on this study, employer compliance with relevant legislation was a great concern for domestic workers. While most of the domestic workers interviewed indicated that they were not registered for UIF, most of the employers interviewed stated that they had registered their employees. Employees indicated that they viewed UIF registration as signifying permanent employment and contributing to feelings of job security. Brizi and Bertolaso (2017) believe that monitoring and enforcement mechanisms, including labour inspection, are important within the context of domestic work because any regulatory framework does not necessarily mirror what is really taking place within the private household. Employers must be compelled to comply with legislation governing the workplace to enhance job security, which is an important characteristic of a humanistic workplace. In her study, Fish (2006) cited participants who mentioned that in predemocratic South Africa, employers were required to register the employment status of domestic workers. Although the intention at that time may have been to exercise control over the domestic worker's whereabouts, this type of strict monitoring may currently be required to further promote the protection of domestic workers.

Wages were also raised as a pertinent factor contributing to a positive work experience. It is important that employees are informed of and accorded their basic rights in terms of minimum wages, working hours and annual leave. This aligns with the findings of Acevedo (2016) who highlights that informational and financial resources, amongst others, should be administered in a manner that affirms human dignity. Understanding that domestic workers may not report violations through a lack of knowledge in this regard, or out of a fear of reprisal, it is important that domestic workers are encouraged to recognise their status as employees and understand the relevant legislation governing their terms and conditions of employment. Employers have a role to play in assisting in this regard. Marais (2016) believes that inspectors from the Department of Labour are in a perfect position to encourage domestic workers to speak out for their rights, and to create an awareness amongst employers of their responsibilities in this regard. Unions, such as the South African Domestic Service and Allied Workers Union (SADSAWU), also have a pivotal role to play in providing information in support of both domestic workers and employers. This may assist in strengthening the relationship between employers and domestic workers, contribute to the sense of well-being flowing from mutual workplace engagement and lead to a caring connectedness forming between employer and employee (Marais, 2016).

\section{Relationship with employer}

Although domestic workers generally reported a positive working relationship with their employers and felt free to discuss issues of concern, one employer perceived that her domestic worker found it difficult to communicate on certain issues, and one domestic worker found communicating about work tools (dishwashing soap) easier than communicating about her own needs (margarine being finished). Employers and managers would benefit from developing trusting and respect-based relationships with employees to enhance positive perceptions of the work experience (Melé, 2016). Nzimakwe (2014) emphasises the importance of the collective and the responsibility that people have to respect each other. Sithole (2001) highlights the South African notion of 'Ubuntu', which focuses on the need for shared compassion, sympathy and participation, and which needs to be reflected in workplaces in creating a humanising work experience. Marais (2016) asserts that the reciprocity inherent in Ubuntu implies a sense of collective well-being and responsibility between employer and employee, which develops through harmonious engagement characterised by kindness, caring and involvement. In turn, these positive emotions are seen to influence the thoughts and actions of those involved in a positive manner. In their study, Bosch and McLeod (2015) found that the more information each party had of each other, the more positively each perceived the interaction to be.

\section{Retirement planning}

Domestic workers did not openly share concerns about retirement planning; however, several of the employers voiced concern about their employees, who may have worked for many years, without the opportunity of saving. Many domestic workers continue to work well after retirement age to survive and provide for the needs of their extended families. Meyiwa (2012) proposes that programmes and policies should be formulated that will contribute towards ending the cycle of poverty that many marginalised workers experience. Marais and Van Wyk (2015) recommend that because of the inability experienced by domestic workers to prepare for post-retirement, social security legislation is required to enable them, together with their employers, to make provision for their retirement. In this regard, the complication of domestic workers rendering their services to more than one employer, both at one time and over time, needs to be borne in mind. 
Retirement planning for marginalised employees is a difficult and contentious arena for South Africa. There is a state social grant system in South Africa that includes pension beneficiaries, but concern exists as to the sustainability of the system. The social grant system expanded rapidly from 4.2 million beneficiaries in 2002, a time of rapid economic growth in the country, to about 17 million in 2017, a time that was, and continues to be, associated with low economic growth (Rossouw, 2017). At the same time, Dubihlela and Dubihlela (2014) highlights that coverage remains inadequate, and that there is a need to further expand social grant expenditure. Employers of domestic workers may enter into a private arrangement to contribute to some form of investment or retirement funding option, but reliance on either the state grant system or the willingness of employers to contribute to retirement is regarded as insufficient.

\section{Respect}

Although domestic workers did not explicitly raise the issue of respect, it was highlighted by employers who expressed their conscious efforts to treat their workers with respect and teach their children to do the same. Respect is integral to humanistic management and a positive work experience (Melé, 2016). Employers would benefit from establishing a value-based culture within the home environment and reinforcing this within the family unit. In turn, domestic workers should be encouraged to speak openly should they experience a lack of respect within the home. Marais (2016) believes that treating domestic workers with respect builds a strong sense of social connectedness that has a positive influence on experiences of subjective well-being. This can lead to the domestic worker developing positive feelings towards the organisation (domestic work context) as described by Melé (2016).

\section{Education and training}

Domestic workers did not raise education and training as a factor in the employment relationship, but it was mentioned by one of the employers. It should be borne in mind that the domestic workers participating in this study were receiving basic computer skills training. Although not discussed as a theme, education and training is an important consideration. As stated earlier, domestic work is often performed by women who have little or no education. Challenging work and growth opportunities are important elements of a positive work experience (Melé, 2016). Employers can assist in this regard by ensuring that the equipment and technology provided in the course of domestic work enable the employee to carry out her duties effectively and efficiently. This aligns with the findings of Acevedo (2012) pertaining to the administration of technological and material resources.

Brizi and Bertolaso (2017) contend that professionalisation of the occupation of domestic work is key to recognising the real value thereof, and that training can empower domestic workers and promote the dignity of the profession. Opportunities for adding tasks that the domestic worker finds personally more satisfying and stimulating, as well as recognition for the depth of responsibility associated with domestic work, could also enhance the positivity of the domestic work experience. There are numerous nongovernmental organisations and other institutions that offer education, training and development opportunities, and study bursaries are also available for qualifying individuals. Marais and Van Wyk (2015) propose the introduction of a developmental mentoring programme to guide domestic workers with the career choices of their children to break any cycle of generational engagement in the sector. It is asserted that employers need to assume ethical and moral responsibility for the most vulnerable of the workforces through creating opportunities for purposeful development.

\section{Conclusion}

This study was aimed at providing a better understanding of the factors that contribute towards a positive work experience for domestic workers, and how employers can enhance the domestic work experience. This can be performed through creating a humanistic workplace and elevating domestic work to its rightful place as an enabling and worthy occupation.

The findings of the study revealed that domestic workers highlighted job security, wages, working conditions and relationship with employers as important factors. Employers of domestic workers, in turn, centred on compliance with legislation, part of the family, retirement planning and respect. The most notable theme emerging was that of employer compliance with the relevant legislation, as this provides domestic workers with a greater sense of job security and peace of mind. Employer compliance can be achieved through monitoring by the Department of Labour and unions such as SADSAWU. Strategies recommended in promoting a positive work experience include nurturing a trust-based relationship between employer and employee based on open communication, making provision for retirement planning and establishing a value-based culture within the home. Furthermore, understanding that career opportunities may be limited for many domestic workers, attending to their personal growth and development is important.

Recommendations in terms of future research include a study determining the relative significance of factors contributing towards a positive work experience for domestic workers. Furthermore, a study exploring the emotional and relational complexity of the domestic employment relationship is proposed. Finally, a study exploring strategies to professionalise domestic work in order to more closely protect and regulate this sector is recommended. This would assist in acknowledging the value that domestic work adds to the South African economy.

\section{Acknowledgements Competing interests}

The authors declare that they have no financial or personal relationships that may have inappropriately influenced them in writing this article. 


\section{Authors' contributions}

The primary research study was undertaken by M.T. in fulfilment of the requirements of an MComm (IOP) degree. This article was written by B.d.V., who synthesised the main aspects of the study with additional literature in support of the research objectives, findings and recommendations, with input from M.T.

\section{Funding information}

This research received no specific grant from any funding agency in the public, commercial, or not-for-profit sectors.

\section{Data availability statement}

Data sharing is not applicable to this article as no new data were created or analysed in this study.

\section{Disclaimer}

The views and opinions expressed in this article are those of the authors, and not an official position of the organisations with which the authors are affiliated.

\section{References}

Acevedo, A. (2012). Personalist business ethics and humanistic management: Insights from Jacques Maritain. Journal of Business Ethics, 105, 197-219. https://doi. org/10.1007/s10551-011-0959-x

Ally, S. (2008). Domestic worker unionisation in post-apartheid South Africa: Demobilisation and depoliticization by the democratic state. Politikon: South African Journal of Political Studies, 35(1), 1-21. https://doi.org/10.1080/02589340802113014

Blaauw, P.F., \& Bothma, L.J. (2010). The impact of minimum wages for domestic workers in Bloemfontein, South Africa. SA Journal of Human Resources Management, 8(1), 1-7. https://doi.org/10.4102/sajhrm.v8i1.216

Bosch, T., \& McLeod, C. (2015). The relationship between female domestic workers and their employers in Cape Town, South Africa. Global Media Journal African Edition, 9(2), 134-155.

Braun, V., \& Clarke, V. (2006). Using thematic analysis in psychology. Qualitative Research in Psychology, 3(2), 77-101. https://doi.org/10.1191/14780887 06qp063oa

Brizi, M.R., \& Bertolaso, M. (2017). The long road towards sustainability: The contribution of domestic work. In: 'Il volto del lavoro professionale. Servizio alla famiglia e alla società', Atti del Convegno 'The Heart of Work-Quale anima per lavoro professionale', Pontificia Università della Santa Croce, Roma, 19-20 October 2017

Bryman, A., \& Bell, E. (2011). Research methodology: Business and management contexts. Cape Town: Oxford University Press.

Budlender, D. (2010). What do time use studies tell us about unpaid care work? Evidence from seven countries. In: D. Budlender (Ed.), Time used studies and unpaid care work (p. 36). New York: Routledge.

Businesstech. (2018). How much South Africans are paying domestic workers in 2018 Retrieved from https://businesstech.co.za/news/finance/227253/how-muchsouth-africans-are-paying-domestic-workers-in-2018/.

Byrd, N.Z. (2010). The dirty side of domestic work: An underground economy and the exploitation of undocumented workers. DePaul Journal for Social Justice, 3(10), 245-276.

Campbell, I., \& Price, R. (2016). Precarious work and precarious workers: Towards an improved conceptualisation. The Economic and Labour Relations Review, 27(3) 314-322. https://doi.org/10.1177/1035304616652074

Carr, S.C., Parker, J., Arrowsmith, J., Haar, J., \& Jones, H. (2017). Humanistic management and living wages: A case of compelling connections? Humanist Management Journal, 1(2), 215-236. https://doi.org/10.1007/s41463-0160018-y

Cock, J. (1980). Maids and madams: A study in the politics of exploitation. Johannesburg: Ravan Press.

Department of Labour. (2001). Domestic workers report: Investigation into minimum wages and conditions of employment of domestic workers. Retrieved from https://www.gov.za/departmentoflabour/papers.htm

Department of Labour. (2018). Basic Conditions of Employment Act (75/1997). Amendment of Sectoral Determination 7: Domestic Worker Sector, South Africa, Pretoria: South African Government.
Dierksmeier, C. (2016). What is humanistic about humanistic management? Humanistic Management Journal, 1, 9-32. https://doi.org/10.1007/s41463-016-0002-6

Dilata, X.P. (2008). Between sisters: A study of the employment relationship between African domestic workers and African employers in the townships of Soweto. Doctoral dissertation, Faculty of Arts, University of the Witwatersrand Johannesburg. Retrieved from http://wiredspace.wits.ac.za/handle/10539/7611.

Dinkelman, T., \& Ranchhod, V. (2012). Evidence on the impact of minimum wage laws in an informal sector: Domestic workers in South Africa. Journal of Development Economics, 99, 27-45. https://doi.org/10.1016/j.jdeveco.2011.12.006

Donald, F.M., \& Mahlatji, L. (2006). Domestic workers experiences of power and oppression in South Africa. Journal of Psychology in Africa, 16(2), 205-213. https://doi.org/10.1080/14330237.2006.10820124

Dubihlela, J., \& Dubihlela, D. (2014). Social grants impact on poverty among the female-headed households in South Africa: A case analysis. Mediterranean Journal of Social Sciences, 5(8), 160-167.

Du Preez, J., Beswick, C., Whittaker, L., \& Dickinson, D. (2010). The employment relationship in the domestic workspace in South Africa: Beyond the apartheid legacy. Social Dynamics, 36(2), 395-409. https://doi.org/10.1080/02533952.2010.483826

Du Toit, D. (2010). Extending the frontiers of employment regulation: The case of domestic employment in South Africa. Law, Democracy \& Development, 14(1), 1-27. https://doi.org/10.4314/Idd.v14i1.6

Finnemore, M., \& Koekemoer, G.M., (2018). Introduction to labour relations (12th edn.). Cape town, South Africa: Lexis Nexis.

Fish, J.N. (2006). Engendering democracy: Domestic labour and coalition-building in South Africa. Journal of Southern African Studies, 32(1), 107-127. https://doi. org/10.1080/03057070500493811

Gaitskell, D., Kimble, J., Maconachie, M., \& Unterhalter, E. (1984). Class, race and gender: Domestic workers in South Africa. Review of African Political Economy, 27(28), 86-108. https://doi.org/10.1080/03056248308703548

Galvaan, R., Peters, L., Smith, T., Brittain, M., Menegaldo, A., Rautenbach, N., \& Wilson-Poe, A. (2015). Employers' experiences of having a live-in domestic worker: Insights into the relationship between privilege and occupational justice.
South African Journal of Occupational Therapy, 45(1), 41-47. https://doi. South African Journal of Occupational
org/10.17159/2310-3833/2015/v45no1a7

Hansen, K.T. (1989). Distant companions: Servants and employers in Zambia 19001985. Ithaca, NY: Cornell University Press.

Henderson, R., \& Anetos, P. (2018). Domestic workers: The one million helpers behind the economy. Sunday Times. Retrieved from https://www.pressreader.com/ south-africa/sunday-times/20180513/282445644698806.

Hua, J., \& Ray, K. (2010). The 'practice of humanity'. Feminist Media Studies, 10(3), 253-267. https://doi.org/10.1080/14680777.2010.493644

ILO. (2010). Decent work for domestic workers. International Labour Conference 2009, 99th Session. Geneva: International Labour Office. August 2010.

Khunou, K. (2018). Domestic workers rights: A legal and practical guide. SocioEconomic Rights Institute of South Africa. Retrieved from http://www.seri-sa.org/ images/SERI_Domestic_Workers_Rights_Guide_Draft_2_reprint.pdf.

Kwele, D., Nimako, C., Zwane, X., \& Chrysler-Fox, P. (2015). The psychological contract between domestic workers and their employers in South Africa. Working paper. Johannesburg: University of Johannesburg. Retrieved from https://www. researchgate.net/profile/Pharny Chrysler-Fox/publication/307852786 The researchgate.net/profile/Pharny_Chrysler-Fox/publication/307852786_The psychological_contract_between_domestic_workers_and_their_employers_in
South_Africa/links/57d0172e08ae6399a389ce38/The-psychological-contractbetween-domestic-workers-and-their-employers-in-South-Africa.pdf.

Lutz, H. (2002). At your service madam! The globalization of domestic service. Feminist Review, 70, 89-104. https://doi.org/10.1057/palgrave/fr/9400004

Mabilo, M. (2018). Women in the informal economy: Precarious labour in South Africa. Unpublished master's dissertation. Stellenbosch, South Africa: Stellenbosch University.

Maboyana, Y., \& Sekaja, L. (2015). Exploring the bullying behaviours experienced by South African domestic workers. Journal of Psychology in Africa, 25(2), 114-120. https://doi.org/10.1080/14330237.2015.1021511

Magwaza, T. (2008). Effects of domestic workers act in South Africa: A steep road to recognition. Agenda, 22(78), 79-92.

Mangqalaza, H. (2012). The economic worth of domestic workers in South Africa. Unpublished master's dissertation. Tshwane, South Africa: Tshwane University of Technology.

Mantouvalou, V. (2006). Servitude and forced labour in the 21st century: The human rights of domestic workers. Industrial Law Journal, 35(4), 395-414. https://doi. rights of domestic workers.

Marais, C. (2014). Lived realities of domestic workers within the South African labour legislative context: A qualitative study. Unpublished doctoral dissertation. Vaal Triangle Campus, South Africa: North-West University.

Marais, C. (2016). Caring and connectedness in the context of domestic worke employment in South Africa. Journal of Psychology in Africa, 26(3), 237-245. https://doi.org/10.1080/14330237.2016.1185903

Marais, C., \& van Wyk, C. (2015). Future directiveness within the South African domestic workers' work-life cycle: Considering exit strategies. Indo-Pacific Journa of Phenomenology, 15(1), 1-14. https://doi.org/10.1080/20797222.2015.1049896

Meiring, T., Kannemeyer, C., Potgieter, E. (2018). The gap between rich and poor: South African society's biggest divide depends on where you think you fit in SALDRU Working Paper Number 220. Cape Town: SALDRU, UCT.

Melé, D. (2013). Antecedents and current situation of humanistic management African Journal of Business Ethics, 7(2), 52-61. https://doi.org/10.4103/18177417.123079 
Melé, D. (2016). Understanding humanistic management. Humanistic Management Journal, 1, 33-55. https://doi.org/10.1007/s41463-016-0011-5

Meyiwa, T. (2012). Domestic workers' rights in global development indicators Agenda, 26(1), 54-66. https://doi.org/10.1080/10130950.2012.674279

Nzimakwe, T.I. (2014). Practising ubuntu and leadership for good governance: The South African and continental dialogue. African Journal of Public Affairs, 7(4), 30-41.

Parrenas, R.S. (2001). Servants of globalization: Women, migrant and domestic work. CA: Stanford University Press.

Qayum, S., \& Ray, R. (2003). Grappling with modernity: India's respectable classes and the culture of domestic servitude. Ethnography, 4(4), 520-555. https://doi. org/10.1177/146613810344002

Rossouw, J. (2017). Social grants matter: They support 33\% of South Africans. University of Johannesburg. https://www.wits.ac.za/news/latest-news/in-theirown-words/2017/2017-02/social-grants-matter-they-support-33-of-southafricans.html

Roy, N.S. (2011). In India, maids need protection and respect. New York Times. Retrieved from https://www.nytimes.com/2011/07/13/world/asia/13ihtletter13.html.

Ryan, L. (2016). 22 easy ways to humanize your workplace. Retrieved from https:// www.forbes.com/sites/lizryan/2016/10/31/22-easy-ways-to-humanize-yourworkplace/\#5688bfa6154e.

Sithole, J. (2001, 15 May). Africa can only use own culture to influence globalization Afrol News.. Retrieved from http://www.afrol.com/html/News2001/afr020_ culture_econ.htm.
South African Government. (2019). Old age pension. Retrieved from https://www.gov. $\mathrm{za} /$ services/social-benefits-retirement-and-old-age/old-age-pension.

South African Revenue Services. (2017). Unemployment insurance fund. Retrieved from http://www.sars.gov.za/TaxTypes/UIF/Pages/default.aspx.

Spitzeck, H. (2011). An integrated model of humanistic management. Journal of Business Ethics, 99(1), 51-62. https://doi.org/10.1007/s10551-011-0748-6

Stats SA (Statistics South Africa). (2018). Quarterly Employment Statistics, March 2018. Pretoria: Statistics South Africa.

Stats SA (Statistic South Africa). (2019). Quarterly Labour Force Survey, Quarter 1: 2019. Pretoria: Statistics South Africa.

Thompson, S. (n.d.). Challenges of humanistic management. Small Business - Chron com. Retrieved from http://smallbusiness.chron.com/challenges-humanisticmanagement-64545.html

Tolla, T. (2013). Black women's experiences of domestic work: Domestic workers in Mpumalanga. Unpublished dissertation. Cape Town, South Africa: University of Cape Town.

Weybright, E.H., Caldwell, L.L., Hui, X., Wegner, L., \& Smith, E.A. (2017). Predicting secondary school dropout among South African adolescents: A survival analysis approach. South African Journal of Education, 37(2), 1-11.

Wilson, S., \& Maclean, R. (2011). Research methods and data analysis for Psychology. London: McGraw-Hill.

Yenn, T.Y. (2014). Modeling good values by treating domestic workers with respect Retrieved from https://www.aware.org.sg/2014/03/modeling-good-values-bytreating-domestic-workers-with-respect/. 